ted by the various working groups of SCAR, Fifield had the task of producing a readable account of the achievements of Antarctic science, with special reference to the role of SCAR. This could have been no easy task, and one gets the impression that the author experienced more than the usual feeling of relief when the manuscript finally went to the printers. Nevertheless, Fifield has succeeded very well and produced a useful guide to the main fields of Antarctic research.

In places the technical language of the formal report shows through: 'Studies of how plants and animals survive subzero temperatures will continue ...', and there are examples of repetition from one chapter to another which more rigorous editing might have removed. Some of the diagrams could have been improved. They often bear the mark of having been taken off the shelf rather than drawn to illustrate the text. And a list of acronyms would have been invaluable. However, Fifield has topped and tailed the material he received so as to produce a work that hangs together and for the most part reads easily. I found the chapter on the upper atmosphere, never an easy subject, particularly well treated.

The book will be of value to those, specialist and nonspecialist alike, who need a quick update in Antarctic science. It should be required reading for those groups that are newly developing their plans for the research programmes that will qualify their nations for consultative status under the Antarctic Treaty or full membership of SCAR. Many people, particularly those nearer to the hub of Antarctic science, might have wished for a more critical analysis of the way SCAR works, or at times, fails to work. It is one thing to read (p 110) that a working group 'determines priorities for future research', but the crucial question is whether those priorities are followed up. How well is SCAR carrying out its constitutional function of 'furthering the co-ordination of scientific activity in the Antarctic, with a view to framing a scientific programme of circumpolar scope and significance'? Many and significant changes have taken place since the SCAR constitution was drawn up at the Hague in 1958. SCAR delegates, nominated by National Academies, are now less likely to be in a position to commit their nation's resources to a particular scientific programme than they were when the programmes of the IGY were being drawn up. Programme managers, or their equivalents, have a vital role to play in the organisation of programmes and the commitment of logistic resources to them. The conflicting styles of institute-based research and programmes arising from peer-reviewed grant applications have to be reconciled.

Richard Fifield's book does not set out to discuss these points, though it recognises their existence. What it does set out to do, to present to the public the results of scientific research in the Antarctic, it does very well, and SCAR and the Antarctic community generally, has reason to be grateful to Fifield. (W. Nigel Bonner, British Antarctic
Survey, High Cross, Madingley Road, Cambridge CB3 OET.)

\section{BRIEF REVIEWS}

HUNTERS, PASTORALISTS AND RANCHERS. Ingold, T. 1988. Cambridge, Cambridge University Press. $326 \mathrm{p}$, illustrated, soft cover. ISBN 0521358876 . $£ 10.95$; US $\$ 15.95$.

Subtitled 'Reindeer economies and their transformations'; the paperback edition of a book which first appeared in 1980 (reviewed in Polar Record 20 (127): 378-9 (1981), with a rebuttal from the author in the following issue, p 457). The original reviewer, Ian Whitaker, now writes 'Although I do not agree with all his argument, it is good to see this thought-provoking monograph available to a wider readership. Ingold's experience of reindeer management, springing from his fieldwork among the Skolt Lapps (Sami) of northern Finland, gives the book many insights from the field, to supplement his data derived from the library'

THE SOVIET MARITIME ARCTIC. Brigham, L. W. and Gately, E. M. (editors). 1988. Woods Hole Oceanographic Institution Technical Report WHOI-88-5. 67 p, illustrated, soft cover.

A summary of an international workshop held May 10-13 1987 by the Marine Policy Center of Woods Hole, involving 28 participants from Canada, Britain, Norway and the US. The meetings provided '... a forum for Western scholars to examine and discuss Soviet domestic international policies regarding the Arctic Ocean' and addressed ... 'strategic, geographic, historical, legal, scientific, technological, transportation, geopolitical and resource development' concerns. The report includes abstracts of 15 contributed papers and an edited transcript of the concluding discussion; report abstracts are in English and Russian.

STUDENT RESEARCH IN CANADA'S NORTH. Adams, W.P. and Johnson, P. G. (editors). 1988. Ottawa, Association of Canadian Universities for Northern Studies. 596 p, illustrated, soft cover. ISBN 0-921421-02-8. Can $\$ 25.00$ in Canada, Can $\$ 35.00$ including postage elsewhere, Can $\$ 10.00$ for students.

These proceedings, covering the first National Student Conference on Northern Studies, held in Ottawa in November 1986, ‘... represent the first comprehensive record of the level and nature of student activity in Northern Studies in Canada's universities today'. The wholly admirable objective of the conference was that the 'next generation' of Northern scholars should get to know each other, become familiar with each others's work, and be sensitive to the multidisciplinary context of their research. There are 101 papers, many of very high standard, grouped under Physical Sciences, Life Sciences and Human Sciences, with abstracts in English and French. 
Available from ACUNS, 130 Albert St, Suite 1915, Ottawa, Canada K1P 5G4.

GUIDE TO THE WILLIAM A. EGAN PAPERS 1940-84. Tabbert, Barbara M. 1987. ElmerE. Rasmuson Library Occasional Papers 13. Fairbanks, University of Alaska Fairbanks. 17 p, illustrated, soft cover. ISBN 0937592-10-2. US $\$ 12.00$ inc postage and handling.

William A. Egan (1914-84) was elected to the council of his hometown Valdez, Alaska in 1937, and rose through stages of territorial representative and senator to become three times Governor of Alaska, in 1958, 1962 and 1970. His collected papers, which include official correspondence, speeches, posters, bulletins and other literature cover the period in which Alaska achieved statehood. This guide is available direct from the Elmer $E$. Rasmuson Library, University of Alaska Fairbanks, Fairbanks AK 99775-1005, USA.

\section{In brief}

DISTEMPER INNORTHERN CANADA. An outbreak of distemper is affecting sledge dogs at many communities in northern Canada. In Pond Inlet alone at least 65 out of 80 of the town's working dogs have died. All stray dogs have been shot; the only survivors are those fortunate enough to have been vaccinated against the disease. The Royal Canadian Mounted Police routinely vaccinate dogs against rabies. Distemper vaccine was formerly included in the rabies shots, but this has been discontinued.

Losses will have serious consequences for Inuit hunters. Many use their teams to hunt seals for family consumption, and generate additional income by acting as guides in licensed sport hunts for polar bears, which are required by law to use dog teams. In a cash-poor local economy, already severely hit by the sealskin and fur boycotts promoted by animal rights groups, such hunting is an important source of revenue. During the period of two years or more needed to replace the dogs, hunters who guide sport hunts could lose $\$ 10,000$ to $\$ 20,000$ each. The epidemic is believed to be spread by foxes, whose numbers were up this year; it has spread as far as Greenland. (Source: Heather Myers, Pond Inlet, NWT, Canada.)

SOVIET AND CANADIAN SKIERS AT THE NORTH POLE. A party of nine Soviet and four Canadian skiers, led by Dmitri Shparo, left Arctic Cape, the northernmost point of Severnaya Zemlya, on 3 March to trek to Canada across the ice of the Arctic Ocean. Members were reported to be carrying $40 \mathrm{~kg}$ back-packs, and to receive additional supplies from air-drops. They reached the North Pole in late April. All were in good health after their 53-day journey, in which they covered almost $1000 \mathrm{~km}$. The party arrived to find a reception of 200 awaiting them, including Canadian and Soviet ministers, officials and journalists, tourists, and a group of scientists from a nearby ice station, with supplies of champagne and fresh fruit. On the following day they set off for Ellesmere Island, $700 \mathrm{~km}$ away, which they hoped to reach in early June. (Sources: Soviet Weekly, 12 March 1988: Daily Telegraph, 29 May 1988.)
ANTARCTIC MINERALS RESOURCES DISCUSSIONS. Delegates from 27 countries attended the eleventh and probably penultimate session of the Antarctic Minerals Regime discussions, held in Wellington, New Zealand. The Chairmanship, Chris Beeby, Deputy Secretary in the New Zealand Department of Foreign Affairs, reported that it was still not certain whether mineral resources would ever be exploited. The purpose of the talks was to ensure that, should exploitation take place, it would be regulated in an acceptable manner, so as not to threaten either the peace and stability that the Antarctic Treaty had maintained, or to present unacceptable risks to the Antarctic environment. All countries that share these concerns are welcome to become parties to the convention and participate in activities in the region. The session had proceeded in a smooth and constructive fashion, with all delegations showing a willingness to bring the negotiations to a successful conclusion. The talks began in 1982: the final negotiating meeting is scheduled for May 1988. (Source: ANARE News, March 1988.)

\section{NORTHERN STUDIES GRANTS TO CANADIAN} UNIVERSITIES. The Canadian Department of Indian Affairs and Northern Development has recently announced an allocation of Can\$748,000 to 26 universities in 1988-89, for studies under the Northern Scientific Training Program (NSTP). Starting in 1961, the programme has provided financial assistance totalling $\$ 9.5$ million to Canadian universities that offer training to students engaged in specialized northem studies; in 1987-88 it funded 308 students with payments averaging $\$ 2426$ per project. The highest grants for 1988 studies have been awarded to the Boreal Institute for Northern Studies, University of Alberta $(\$ 63,000)$ and the Centre for Northern Studies and Research, McGill University $(\$ 53,000)$. The Donner Canadian Foundation, a private philanthropic organization, has awarded Can $\$ 92,000$ to the Consortium for Devolution Research, based at the University of Alberta, to study the devolution of power from the Government of Canada to the governments of the 